\title{
Water footprints of cities - indicators for sustainable consumption and production
}

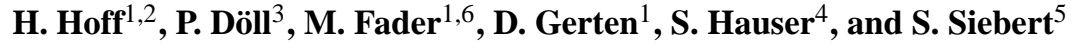 \\ ${ }^{1}$ Potsdam Institute for Climate Impact Research, Telegrafenberg, 14473 Potsdam, Germany \\ ${ }^{2}$ Stockholm Environment Institute, Linnégatan 87D, 10451 Stockholm, Sweden \\ ${ }^{3}$ Institute of Physical Geography, Goethe University Frankfurt, Altenhöferallee 1, 60438 Frankfurt, Germany \\ ${ }^{4}$ International Institute of Tropical Agriculture, Ibadan, PMB 5320, Oyo State, Nigeria \\ ${ }^{5}$ Institute of Crop Science and Resource Conservation, University of Bonn, Katzenburgweg 5, 53115 Bonn, Germany \\ ${ }^{6}$ Institut Méditerranéen de Biodiversité et d'Ecologie marine et continentale (IMBE), Aix-Marseille Université, CNRS, IRD, \\ Univ. Avignon, Technopôle Arbois-Méditerranée, Bât. Villemin - BP 80, 13545 Aix-en-Provence cedex 04, France
}

Correspondence to: H. Hoff (hhoff@ pik-potsdam.de)

Received: 30 January 2013 - Published in Hydrol. Earth Syst. Sci. Discuss.: 28 February 2013

Revised: 24 September 2013 - Accepted: 2 December 2013 - Published: 16 January 2014

\begin{abstract}
Water footprints have been proposed as sustainability indicators, relating the consumption of goods like food to the amount of water necessary for their production and the impacts of that water use in the source regions. We further developed the existing water footprint methodology, by globally resolving virtual water flows from production to consumption regions for major food crops at 5 arcmin spatial resolution. We distinguished domestic and international flows, and assessed local impacts of export production. Applying this method to three exemplary cities, Berlin, Delhi and Lagos, we find major differences in amounts, composition, and origin of green and blue virtual water imports, due to differences in diets, trade integration and crop water productivities in the source regions. While almost all of Delhi's and Lagos' virtual water imports are of domestic origin, Berlin on average imports from more than $4000 \mathrm{~km}$ distance, in particular soy (livestock feed), coffee and cocoa. While $42 \%$ of Delhi's virtual water imports are blue water based, the fractions for Berlin and Lagos are 2 and $0.5 \%$, respectively, roughly equal to the water volumes abstracted in these two cities for domestic water use. Some of the external source regions of Berlin's virtual water imports appear to be critically water scarce and/or food insecure. However, for deriving recommendations on sustainable consumption and trade, further analysis of context-specific costs and benefits associated with export production will be required.
\end{abstract}

\section{Introduction}

Agriculture causes by far the largest direct human water use, including large amounts of green and blue water required to grow food and other crops (Shiklomanov, 2000; Foley et al., 2005; Rost et al., 2008; Döll et al., 2012). Green water is the plant available soil water directly from rainfall, supporting terrestrial ecosystems and most agricultural systems, while blue water is the water in rivers, lakes and groundwater, available for irrigation and other purposes, for example, municipal and industrial use. With globalization, trade in food commodities is growing faster than food production (Anderson, 2010; WTO, 2010), facilitating spatial separation of consumption and production, also beyond country and continental borders (Erb et al., 2009; Hoff; 2009). Consequently, the gap in the physical trade balance between net food importing (in particular industrialized) and net food exporting countries has been widening (Bruckner et al., 2012). The EU for example has doubled its net food imports from countries outside of Europe over the past decade (von Witzke and Noleppa, 2010).

Globally, the amount of water consumed for producing export food commodities, so-called "virtual water", which is associated with traded goods, has doubled over the past 2 decades (Dalin et al., 2012). With growing food trade, and more recently also foreign direct investment in land and water (Anseeuw et al., 2012), local resource exploitation - and 
in some cases also degradation - is increasingly driven by external food demands, dietary preferences and purchasing power. The outsourcing of food production to distant, potentially water-scarce and food-insecure regions raises questions about the sustainability of consumption, production and trade patterns (Lenzen et al., 2013; WWF, 2012). Sustainable management of water resources is no longer a local or national issue only.

Water footprints have been proposed as sustainability indicators (Chapagain and Hoekstra, 2004; WWF, 2009; Daniels et al., 2011), because they trace flows of commodities and associated virtual water from the regions of production to the regions of consumption. While flows of virtual water between nations have been quantified by several authors (e.g., Chapagain and Hoekstra, 2004; Hanasaki et al., 2010; Liu and Yang, 2010; Fader et al., 2011), there is little information on "true" water footprints in the sense of Ridoutt and Pfister (2010) that is, the "impacts associated with water appropriated into product[s]" in the source regions, which would require analysis at sub-national scale. Such true water footprints would need to include detailed information on water scarcities and water-related opportunity costs of food production in the source regions (Daniels et al., 2011; Ridoutt and Huang, 2012; Hoekstra and Mekonnen, 2012). As an initial step towards local impacts of food production in the source regions, Hoekstra and Mekonnen (2011) and Pfister et al. (2011) computed blue water scarcity at the river basin scale, by comparing consumptive blue water use to availability. However, they did not relate the water scarcity indicators in the source regions to virtual water flows across grid cells, basins or country boundaries for determining water footprints that are caused by the consumption of goods outside of the source region.

Our analysis of water footprints (understood here as the water-related impacts in the domestic and international source regions, the latter being called "external water footprints") generates new information in support of sustainable consumption and production. We computed and analyzed globally, at high spatial resolution of 5 arcmin, green and blue virtual water flows related to food crops among and for the first time also within countries. The goal was to identify in more detail source regions of virtual water flows and consumption hotspots such as cities. Our analysis is consumption based. It calculates the water required in the source regions for producing primary crop commodities consumed in the importing regions (not including however the consumption of commodities which are primarily traded in processed form, such as sugar cane). Consumption of food crops also includes their use as livestock feed or for producing bioenergy. Livestock feed other than food crops and imports of livestock products are not included in our analysis, neither do we account for non-food crop commodities such as cotton.

Cities with their high population density are centers of consumption and net imports of food (note that we use the term "import" also for inflows into cities from domestic sources). They already host $50 \%$ of global population (on only about $2 \%$ of the global land area - Bicheron et al., 2008), projected to reach $70 \%$ by 2050 (UNPD, 2012). Their water and other resource demands are growing faster than national averages, not only because of further urbanization, but also because of their more rapid economic development and changing lifestyles and diets, for example, higher fractions of livestock products (e.g., Liu and Savenjie, 2008). The immediate hinterland of many cities can no longer fulfill their water (and other resource) demands for food production, so that their water footprints expand rapidly, also into other countries and continents. While cities also use water for producing non-agricultural goods and services, these uses are mostly non-consumptive and smaller than food water demands.

In an exemplary manner, we applied our analysis to Berlin (Germany), Delhi (India) and Lagos (Nigeria), which represent food consumption and import patterns of a developed, a newly industrialized, and a developing country, respectively. Taking into account additional local information, we demonstrate the effects of different diets, countries' integration in world markets, and crop water productivities and local conditions in the source regions, on water footprints.

In our analysis, we distinguished green and blue virtual water flows, as the impacts of blue water use from surface and groundwater for irrigation are different from the impacts of green water use directly from precipitation. In particular in water-scarce areas, blue water use is more detrimental to other direct human water uses and to aquatic ecosystems, while green water use for cropland competes with the demands of other terrestrial ecosystems. Additionally, both types of water use may lead to water pollution, which often aggravates water scarcity, depending on farming practices.

\section{Methods}

\subsection{Calculation of crop commodity and virtual water flows and corresponding water footprints of cities}

While previous analyses (with the exception of a few national case studies, e.g., Faramarzi et al., 2010; Verma et al., 2009; Ma et al., 2006) addressed virtual water flows only between countries, our novel approach identifies globally at grid cell level (5 arcmin resolution) crop production surpluses relative to local demand and from that potential export grid cells. By combining those with grid cell specific crop-water use and bi-national trade data, we determine detailed flows of primary crop commodities and associated virtual water within and between countries (Fig. 1).

For calculating crop production and crop water use, we applied the Global Crop Water Model (GCWM) (Siebert and Döll, 2010). Distinguishing rainfed and irrigated crops according to Portmann et al. (2010) and green and blue crop water use, GCWM computes the virtual water content (the amount of water required for producing a unit 


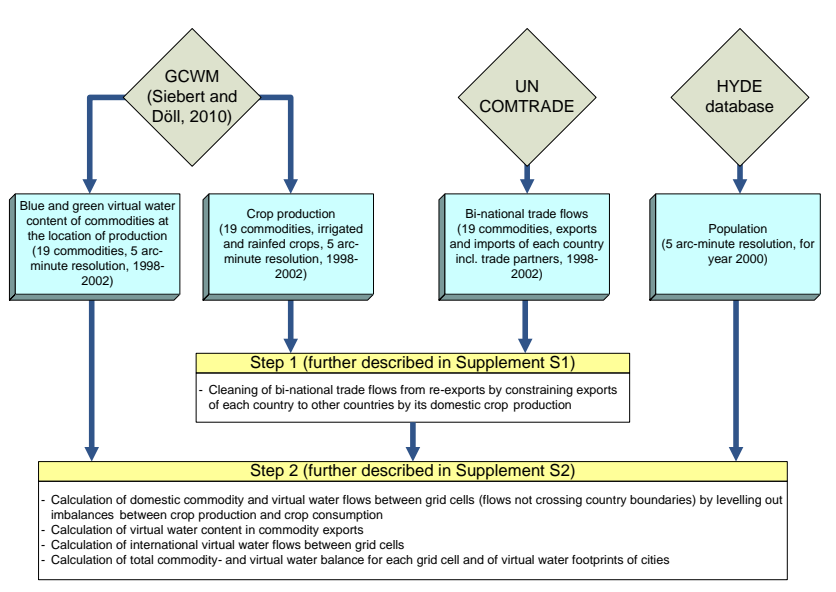

Fig. 1. Flowchart of the analyses, models and data used.

of crop harvest) for 19 major crop groups: wheat, barley, rye, maize, rice, sorghum, millet, pulses, soybeans, groundnuts, sunflower, rapeseed, potatoes, cassava, grapes, citrus, dates, cocoa, coffee (in our analysis for the period 19982002). These crops covered $71 \%$ of the global harvested cropland during this period. In GCWM, simulated drought stress on yields in rainfed agriculture is used to disaggregate national and sub-national crop production and statistics as compiled by Monfreda et al. (2008). Thus, crop production computed by GCWM is harmonized at country level to FAO production statistics around year 2000. More information on GCWM and the data generated by GCWM can be found at: http://www2.uni-frankfurt.de/47878452/6_GCWM_output.

Crop consumption within each country was computed by adding imports of the respective crop commodity to domestic crop production and then subtracting the corresponding commodity exports (Supplement S2). Supplement S1 explains how GCWM crops are related to commodities listed in the COMTRADE database - http://comtrade.un.org/ (last access: 27 January 2013). Therefore, we did not distinguish between food and feed use of these crops, and we did not account for grazing, nor for crop residues as livestock feed. Per capita consumption of each crop was assumed to be the same for all people living in a country (including cities). Production surpluses per crop occur in those grid cells that have a higher per capita production than the country average per capita consumption (calculated from total country production minus exports). Virtual water flows from production surplus (source) areas to deficit (import) areas, in particular cities and other densely populated areas, were calculated according to the following assumptions:

- surplus food production is distributed to the nearest local and national deficit cells first, before the remaining surplus is going into international export; and
- international imports are distributed to the grid cells of the importing country according to their respective share of country population (Supplement S2).

Production surpluses and deficits within each country were leveled out by iteratively allowing commodity flows across larger and larger distances (across $2 \times 2,4 \times 4,6 \times 6$, $12 \times 12,24 \times 24,48 \times 48,72 \times 72,108 \times 108,144 \times 144$, $180 \times 180,216 \times 216,240 \times 240,360 \times 360,432 \times 432$ grid cells) and finally the whole country, if required. Accordingly, green and blue virtual water flows were calculated as the product of commodity flows and the green and blue virtual water content of the respective crop in the source grid cell. When all demands in deficit cells within a country were met from the nearest national surpluses, the remaining surplus cells were identified as export cells for international trade. Green and blue virtual water exports were determined as weighted averages of crop virtual water contents from these surplus cells, according to their respective contribution to the country's total international export (Supplement S2).

Bi-national commodity trade data for the period 19982002 were taken from the COMTRADE database and cleaned from re-exports to the extent possible, constraining commodity exports of each country by its domestic crop production. If the reported crop export was larger than crop production, the exports related to this difference were deleted from the trade flow database and flows redirected from producing to importing countries (Supplement S1). Germany, for example, exported coffee to 31 countries in the year 2000 , although coffee is not grown in Germany. Therefore these trade flows were replaced by flows between the countries from which Germany imported coffee and countries to which Germany exported coffee. Application of this iterative procedure reduced total international virtual water flows by about $12 \%$. Note that we did not analyze effects along the processing chain or related to re-export which might change virtual water contents of commodities. That would require additional tool such as life cycle analysis or input-output analysis and additional assumptions on the composition of processed products and the origin of their ingredients (see Sect. 5.4).

With that, imports of each crop commodity and associated virtual water can be traced back to the source countries and further to the surplus grid cells in the respective country. From that, we calculated volumes and transport distances of green and blue virtual water flows associated with each crop commodity, within and between countries and towards the selected cities Berlin, Delhi and Lagos (Supplement S2).

\subsection{Characterization of the impacts of export production in source countries of Berlin's virtual water imports}

We then characterized some of the main international source regions of imports to Berlin in order to assess local impacts of export production. Note that source regions for Delhi's and Lagos' virtual water imports are mostly domestic, involving 

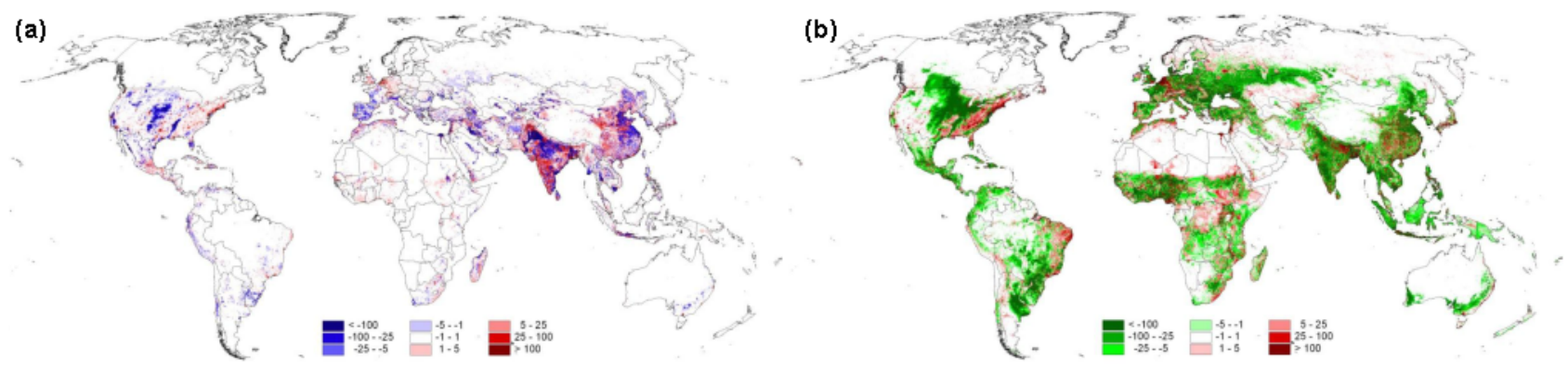

(c)
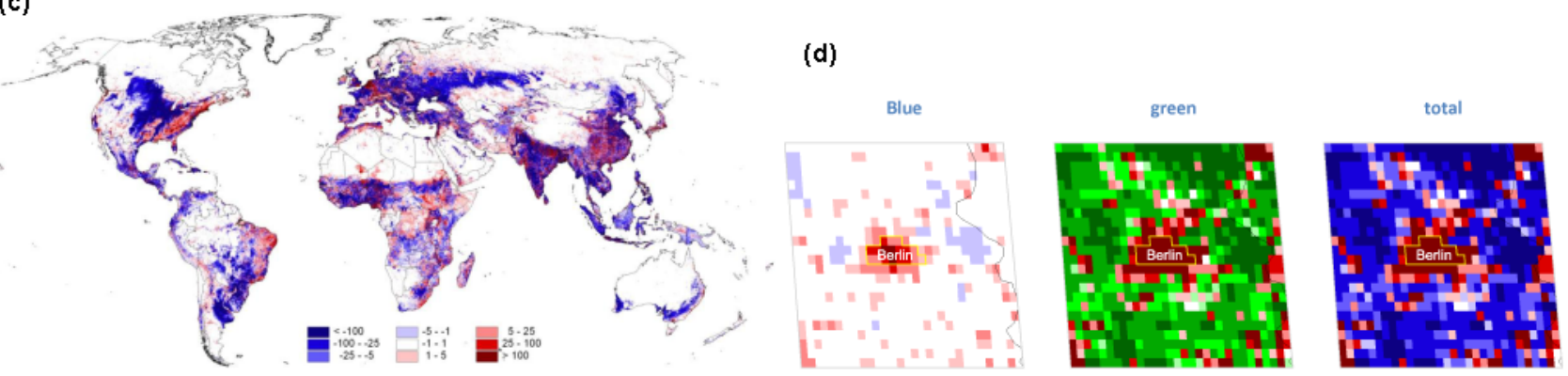

Fig. 2. Blue virtual water flows (a), green virtual water flows (b) total virtual water flows (c) and zoom in for Berlin (d), as caused by food consumption - production imbalances, for all 19 crops considered, for the period 1998-2002 (in mm per year). Negative values indicate crop production surplus relative to consumption and accordingly outflow of virtual water, positive values indicate crop production deficit and inflow of virtual water. A zoom in for the Berlin area is provided in (d), where a yellow polygon shows the grid cells for this analysis assumed to represent the city of Berlin and the black line is the German-Polish border. Maps are shown in Robinson projection.

little international trade and hence there are only very small external footprints. First we determined for the main source countries of Berlin's imports their green and blue water availabilities for food production as well as their own food water requirements, using results from the dynamic global vegetation and water balance model LPJmL, which simulates the water balance, crop water use and crop production (as well as biomass production of other ecosystems) at $0.5 \mathrm{de}-$ gree resolution and also at catchment level (Rost et al., 2008; Gerten et al., 2011). We used the LPJmL model for comparing water availability, which is not calculated by the GCWM model, consistently with water demands for food production. Due to the coarse resolution of LPJmL $\left(0.5^{\circ}\right.$, compared to the 5 arcmin resolution of the GCWM model) it could not be applied to individual cities. Moreover, LPJmL does not calculate the important crops cocoa and coffee. Green water availability for food production was calculated by LPJmL as evapotranspiration from cropland and partly from grazing land. Blue water availability was calculated per river basin, distributing total basin runoff over the grid cells in a basin according to their fractional discharge. Of that, $40 \%$ was assumed to be available for food production (i.e., for irrigation). This estimate of $40 \%$ accounts for environmental flow requirements as well as for spatio-temporal mismatch of water availability and demand (Gerten et al., 2011). Food water requirements were calculated for a typical diet of $3000 \mathrm{kcal}$ per capita and day containing $20 \%$ livestock products (ca. 1/3 of which is assumed to be provided from grazing, the rest from feed crops), based on current crop water productivities of the respective national crop mixes, as calculated with the LPJmL model (Gerten et al., 2011). In addition to food water availability and requirements in the source regions, we also used national indicators such as malnutrition and stunting of children to address food insecurity and water-related opportunity costs of export production. Undernourished population was taken from the FAOSTAT hunger database - http://www.fao.org/ hunger/en/ (last access: 27 January 2013), and nutritional stunting from the WHO database on child growth and malnutrition - http://www.who.int/nutgrowthdb/en/ (last access: 27 January 2013).

\section{Results}

\subsection{Global patterns of net virtual water imports and exports related to food consumption}

Grid cells are net importers of virtual water if their consumptive water use for food crop production is less than the demand for virtual water due to food crop consumption. They are net exporters of virtual water if the opposite is true. The global maps of food-commodity related blue, green and total virtual water flows (Fig. 2) reflect the major crop production regions (or rather crop surplus regions) on the one 
Table 1. Characteristics of virtual water (VW) imports of Berlin, Delhi and Lagos (1998-2002).

\begin{tabular}{lrrrrrr}
\hline & $\begin{array}{r}\text { Green VW } \\
\text { Population } \\
(\text { million })\end{array}$ & $\begin{array}{r}\text { Blue VW } \\
\text { import per capita } \\
\left(\mathrm{m}^{3} \mathrm{yr}^{-1}\right)\end{array}$ & $\begin{array}{r}\text { Total VW } \\
\text { import per capita } \\
\left(\mathrm{m}^{3} \mathrm{yr}^{-1}\right)\end{array}$ & $\begin{array}{r}\text { Avg. green } \\
\text { import per capita } \\
\left(\mathrm{m}^{3} \mathrm{yr}^{-1}\right)\end{array}$ & $\begin{array}{r}\text { Avg. blue } \\
\text { VW transport } \\
\text { distance }(\mathrm{km})\end{array}$ & $\begin{array}{r}\text { VW transport } \\
\text { distance }(\mathrm{km})\end{array}$ \\
\hline Berlin & 3.5 & 628 & 15 & 643 & 4400 & 4200 \\
Delhi & 16.3 & 252 & 182 & 434 & 600 & 200 \\
Lagos & 8.7 & 1203 & 7 & 1210 & 800 & 9000 \\
\hline
\end{tabular}

hand (blue color in Fig. 2a and c, and green color in Fig. 2b) and population concentrations (or crop deficit regions) on the other hand (red color). For example, most grid cells in the eastern United States show higher crop demand than production, while the Midwest of the US has mostly production surpluses. In most regions the pattern of total virtual water flows (Fig. 2c) is dominated by the effects of green water, but in selected regions blue water (i.e., irrigated agriculture) dominates total virtual water flows, in particular in India and China. The mapping of virtual water flows at $5 \mathrm{~min}$ resolution (about $9 \mathrm{~km} \times 9 \mathrm{~km}$ at the equator) also enables the identification of larger cities such as Berlin as being net importers, both of green and blue virtual water flows (Fig. 2d).

\subsection{Virtual water imports of Berlin, Delhi, and Lagos related to food crops}

Cities are net importers of food-crop-related virtual water. When comparing total virtual water imports of the three cities Berlin, Delhi and Lagos, we find significant differences in (i) contributions of different crop commodities to the total imports, (ii) the respective virtual water contents of these crops and (iii) their origin (domestic vs. international) and transport distances. Accordingly, per capita imports of virtual water and also green and blue water fractions vary significantly among the three cities (Table 1).

For consistency with our virtual water flow analysis, we summed up the population of all those $5 \mathrm{~min}$ grid cells that were assigned to the respective city, hence population figures deviate somewhat from official statistics. Virtual water imports with livestock forage (grass, clover, alfalfa, etc.) or with livestock products are not included here.

The contribution of blue water to the total virtual water import is about $0.5 \%$ for Lagos, $2 \%$ for Berlin and $42 \%$ for Delhi. The average importing distances of virtual water to Lagos and Delhi (neglecting here Lagos' very small imports of blue virtual water, which originate from very large distances) are $200-800 \mathrm{~km}$ and hence within the respective country, while in the case of Berlin the source regions are on average more than $4000 \mathrm{~km}$ away and hence outside of Germany and even outside of Europe. Berlin imports more than $60 \%$ of its virtual water from abroad, Lagos only $3.5 \%$ and Delhi $1.4 \%$. Accordingly the supply from the immediate hinterland (sources within $100 \mathrm{~km}$ from the city) is higher for
Delhi and Lagos - $20 \%$ of total virtual water imports - than for Berlin - less than $5 \%$ (see also Fig. 3).

Virtual water contents of crops (or the inverse, crop water productivities) vary by up to a factor of 10 between crops produced in Germany, India and Nigeria and imported by Berlin, Delhi and Lagos, in line with yield differences of similar magnitude (Table 2). Staple crops imported to Berlin from Germany and neighboring countries are particularly low in virtual water contents, thanks to beneficial climate and management conditions. The two major staples wheat and barley imported by Berlin have average virtual water contents of $498 \mathrm{~L} \mathrm{~kg}^{-1}$ (global average for wheat: $1469 \mathrm{~L} \mathrm{~kg}^{-1}$ ) and $639 \mathrm{~L} \mathrm{~kg}^{-1}$ (global average for barley: $1183 \mathrm{~L} \mathrm{~kg}^{-1}$ ). The main staples imported to Lagos, sorghum and millet, have virtual water contents of $5700 \mathrm{~L} \mathrm{~kg}^{-1}$ and $6600 \mathrm{~L} \mathrm{~kg}^{-1}$, respectively.

Berlin's per capita import of virtual water is only about half of that of Lagos, but almost $50 \%$ higher than that of Delhi (Table 1). That higher per capita import of Berlin relative to Delhi - despite much higher crop water productivity in Germany (see Table 2) and also in Germany's neighboring countries (not shown here) - is largely due to the strong contribution of water intensive livestock feed (soy) as well as stimulants (coffee and cocoa), which together account for almost $50 \%$ of Berlin's total water footprint (Fig. 3a). Berlin's largest imports of virtual water are associated with coffee, soy, wheat and barley, and cocoa (in that order). Coffee, soy and cocoa are imported from source regions which are on average $6000 \mathrm{~km}$ or more away, while wheat, barley, rapeseed, rye and maize are produced within an average distance of less than $400 \mathrm{~km}$ from Berlin (i.e., largely within Germany), where crop water productivities are much higher than world averages and virtual water contents accordingly very low. The only significant blue virtual water imports are associated with citrus, rice and potatoes, contributing $0.7,0.4$ and $0.3 \%$, respectively, to Berlin's total virtual water imports. Note that since we have not included cotton (nor any other non-food commodities), a significant part of Berlin's total blue water footprint (Pfister et al., 2011) is not accounted for in our analysis. While the resulting per capita blue virtual water imports of $15 \mathrm{~m}^{3} \mathrm{yr}^{-1}$ (Table 1) are very small, they are still comparable to the $42 \mathrm{~m}^{3} \mathrm{yr}^{-1}$ of per capita domestic water use (115 $\mathrm{Ld}^{-1}$, www.bwb.de), considering that this analysis did 
Table 2. Virtual water contents (VWC) for locally produced maize, pulses and potatoes.

\begin{tabular}{lrrrrrr}
\hline & \multicolumn{2}{c}{ Maize } & \multicolumn{2}{c}{ Pulses } & \multicolumn{2}{c}{ Potatoes } \\
\hline & $\begin{array}{r}\text { Yield } \\
\left(\mathrm{t} \mathrm{ha}^{-1}\right)\end{array}$ & $\begin{array}{r}\text { VWC } \\
\left(\mathrm{m}^{3} \mathrm{~kg}^{-1}\right)\end{array}$ & $\begin{array}{r}\text { Yield } \\
\left(\mathrm{tha}^{-1}\right)\end{array}$ & $\begin{array}{r}\text { VWC } \\
\left(\mathrm{m}^{3} \mathrm{~kg}^{-1}\right)\end{array}$ & $\begin{array}{r}\text { Yield } \\
\left(\mathrm{t} \mathrm{ha}^{-1}\right)\end{array}$ & $\begin{array}{r}\text { VWC } \\
\left(\mathrm{m}^{3} \mathrm{~kg}^{-1}\right)\end{array}$ \\
\hline Germany & 8.60 & 0.44 & 3.26 & 1.09 & 40.22 & 0.10 \\
India & 1.54 & 2.86 & 0.58 & 2.86 & 17.04 & 0.25 \\
Nigeria & 1.16 & 4.00 & 0.42 & 11.11 & 4.43 & 0.29 \\
\hline
\end{tabular}

not account for blue virtual water imports with cotton and that only part of the drinking water use is consumptive.

Delhi, due to its development status, but also its vegetarian tradition, has the lowest meat consumption of the three cities $(3.9 \mathrm{~kg}$ per capita and year in India, vs. $8.5 \mathrm{~kg}$ in Nigeria and $84 \mathrm{~kg}$ in Germany) for the year 2000 according to FAO Food Balance Sheets - FBS, http://faostat3.fao.org/home/ index.html (last access: 27 January 2013) and also the lowest calorie supply (2264 kcal per capita and day in India vs. $2611 \mathrm{kcal}$ in Nigeria and $3423 \mathrm{kcal}$ in Germany, FAO FBS). In addition, very little coffee and cocoa is consumed $(9 \mathrm{~kg}$ per capita in Germany vs. about $0.1 \mathrm{~kg}$ in India and Nigeria, FAO FBS). Note that tea is a more common beverage in India, but its per capita consumption is still about 10 times lower than coffee consumption in Germany according to FAO FBS, and its virtual water contents is about 8 times lower than that of coffee, Chapagain and Hoekstra, 2003). The two main staples rice and wheat (transported less than $200 \mathrm{~km}$ on average) together account for more than $50 \%$, blue virtual water with rice alone for more than $25 \%$ of Delhi's total virtual water imports. When adding millet, sorghum and maize (average transport distance at or below $1000 \mathrm{~km}$ ), $75 \%$ of Delhi's virtual water imports are accounted for. Soy, a typical livestock feed, contributes only $6 \%$ to Delhi's total virtual water imports (compared to $19 \%$ in Berlin), and coffee only contributes $0.2 \%$ (compared to $28 \%$ in Berlin).

Lagos has the highest per capita imports of virtual water with crop commodities of the three cities, which is a result of the very low average crop water productivities of Nigeria (Table 2) and of its immediate neighbors (results not shown). The three staples, cassava (transported less than 200 $\mathrm{km}$ on average), sorghum, and millet (about $800 \mathrm{~km}$ average transport distance) together comprise more than $50 \%$ of Lagos' total virtual water imports. As in the case of Delhi, soy $(<3 \%)$ and cocoa/coffee $(0.1 \%)$ hardly contribute to the city's virtual water imports. Nigerian diets are low in livestock products and stimulants (less than $10 \%$ of German per capita consumption according to FAOSTAT - http://faostat3. fao.org/home/index.html (last access: 27 January 2013)).

Figure 3 shows virtual water imports with crop commodities $\left(x\right.$ axis in $\left.\mathrm{m}^{3} \mathrm{cap}^{-1} \mathrm{yr}^{-1}\right)$ and average import distances ( $y$ axis in km) for Berlin (a), Delhi (b) and Lagos (c). Not depicted are commodities contributing less than ca. $10 \mathrm{~m}^{3}$ $\left(50 \mathrm{~m}^{3}\right.$ in Lagos) green virtual water and less than ca. $1 \mathrm{~m}^{3}$
(Berlin), $10 \mathrm{~m}^{3}$ (Delhi), and $0.1 \mathrm{~m}^{3}$ (Lagos) blue virtual water per capita and year. Bubble sizes depict real commodity imports in $\mathrm{kg}$ for each city. Green and blue virtual water import volumes per crop are additive, but real crop imports are equally depicted by same green and blue bubble sizes of the respective crop. Open circles serve to keep other bubbles underneath visible.

Bubble sizes in Fig. 3a indicate the following: wheat $164 \mathrm{~kg} \mathrm{cap}^{-1} \mathrm{yr}^{-1}$, soy $53 \mathrm{~kg} \mathrm{cap}^{-1} \mathrm{yr}^{-1}$, coffee $9 \mathrm{~kg} \mathrm{cap}^{-1}$ $\mathrm{yr}^{-1}$, cocoa $3 \mathrm{~kg} \mathrm{cap}^{-1} \mathrm{yr}^{-1}$. Average virtual water contents of Berlin's imports are the following: wheat $498 \mathrm{~L} \mathrm{~kg}^{-1}$, soy $1755 \mathrm{~L} \mathrm{~kg}^{-1}$, coffee $15000 \mathrm{~L} \mathrm{~kg}^{-1}$, cocoa $20000 \mathrm{~L} \mathrm{~kg}^{-1}$ (not shown).

Bubble sizes in Fig. $3 \mathrm{~b}$ indicate the following: rice $122 \mathrm{~kg}$ $\mathrm{cap}^{-1} \mathrm{yr}^{-1}$, wheat $66 \mathrm{~kg} \mathrm{cap}^{-1} \mathrm{yr}^{-1}$, pulses $12 \mathrm{~kg} \mathrm{cap}^{-1}$ $\mathrm{yr}^{-1}$, soy $5 \mathrm{~kg} \mathrm{cap}^{-1} \mathrm{yr}^{-1}$. Average virtual water contents of Delhi's imports are the following: rice $1900 \mathrm{~L} \mathrm{~kg}^{-1}$, wheat $2100 \mathrm{~L} \mathrm{~kg}^{-1}$, pulses $3200 \mathrm{~L} \mathrm{~kg}^{-1}$, soy $4200 \mathrm{~L} \mathrm{~kg}^{-1}$ (not shown).

Bubble sizes in Fig. 3c indicate the following: cassava $227 \mathrm{~kg} \mathrm{cap}^{-1} \mathrm{yr}^{-1}$, sorghum $50 \mathrm{~kg} \mathrm{cap}^{-1} \mathrm{yr}^{-1}$, rice $33 \mathrm{~kg}$ $\mathrm{cap}^{-1} \mathrm{yr}^{-1}$, soy $3 \mathrm{~kg} \mathrm{cap}{ }^{-1} \mathrm{yr}^{-1}$. Average virtual water contents of Lagos' imports are the following: cassava $983 \mathrm{~L} \mathrm{~kg}^{-1}$, sorghum $5700 \mathrm{~L} \mathrm{~kg}^{-1}$, rice $3800 \mathrm{~L} \mathrm{~kg}^{-1}$, soy $6800 \mathrm{~L} \mathrm{~kg}^{-1}$ (not shown). The small amounts of blue virtual water with rice and blue and green virtual water with wheat are imported from average distances $>9000 \mathrm{~km}$, which is not shown to scale here.

Figure $3 \mathrm{a}-\mathrm{c}$ also reveal large differences between a crop's contribution to total virtual water imports (in $\mathrm{m}^{3}$, expressed by its position on the $x$ axis) vs. its contribution to total real commodity imports (in kg, expressed by its bubble size), due to the differences in virtual water contents between crops and between source regions (driven by differences in climate and agricultural management). For our further analysis of water footprints, the virtual water import (depicted on the $x$ axis) is the relevant parameter.

\subsection{Origin of Berlin's virtual water imports and water-related criticality of its source regions}

Berlin's virtual water imports originate on average more than $4000 \mathrm{~km}$ away (Fig. 3). A more detailed analysis of the source regions of the crop commodities depicted in Fig. 3a 


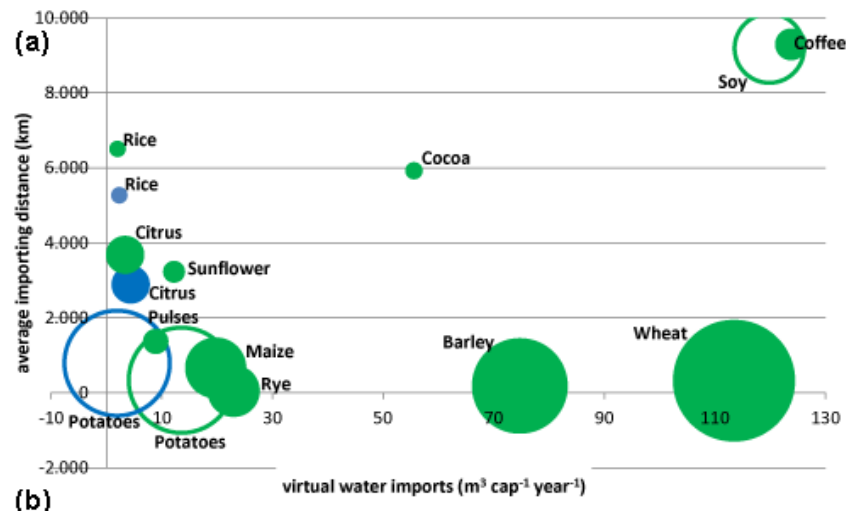

(b)

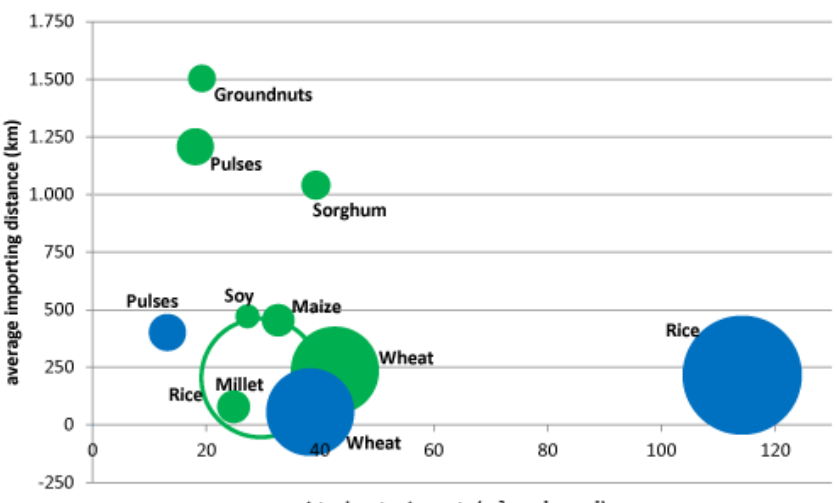

(c)

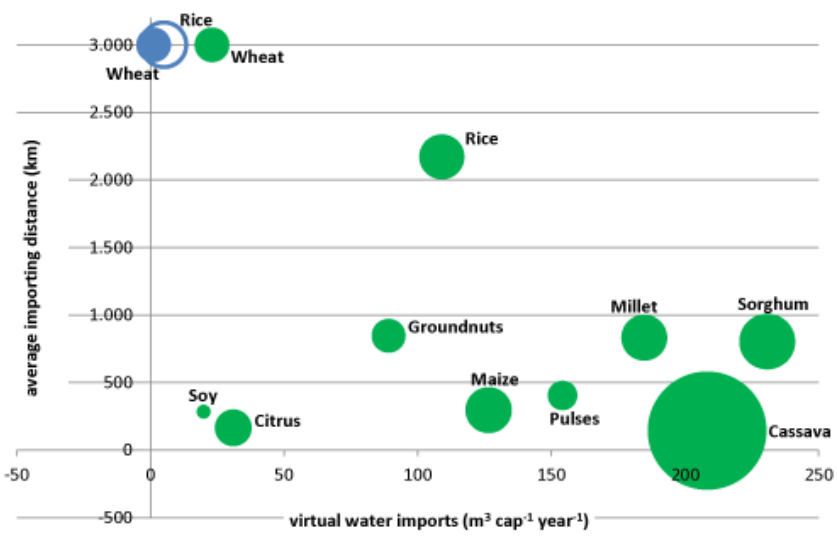

Fig. 3. Virtual water imports, amounts and average importing distances.

reveals that Germany itself is still the largest source country, contributing $39 \%$ of Berlin's total virtual water imports, with wheat from Germany contributing $15 \%$, barley $11 \%$, rapeseed $5 \%$ and rye $3 \%$. Only $0.5 \%$ of Berlin's virtual water imports from Germany are blue. Figure 4 provides an overview of the other major source countries (indicated by thickness of the arrows) and the primary export product to Berlin per country. Brazil is the 2nd largest contributor, providing ca. $14 \%$ of Berlin's virtual water, $2 / 3$ of which is associated with soy beans and the rest with coffee $(0.6 \%$ of total virtual water imports from Brazil are blue). After the

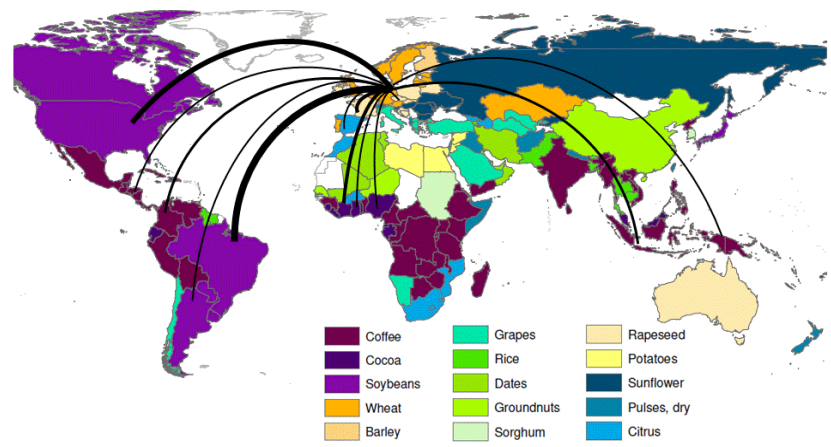

Fig. 4. Berlin's virtual water imports. Country colors indicate the primary export product to Berlin (in terms of virtual water export), arrow widths are proportional to virtual water import volumes (only shown for countries contributing about $1 \%$ or more to Berlin's total virtual water imports).

US as number 3 (ca. $8.5 \%$ of Berlin's total virtual water imports), Ivory Coast is number 4 (ca. $5 \%$ ). As in the case of Ghana (ca. $1.5 \%$ ) and Nigeria (ca. $1 \%$ ) more than $95 \%$ of the virtual water imports from these three West African countries to Berlin are associated with cocoa (blue water fractions of imports from these 3 countries to Berlin are 0,0 and $0.03 \%$, respectively). The largest blue virtual water imports to Berlin are associated with citrus $(0.7 \%$ of total virtual water imports) primarily from Mediterranean countries and rice ( $0.4 \%$ of total) $3 / 4$ of which are from USA, Spain, and Italy combined. WWF (2009) confirms the large virtual water contributions from Brazil and West Africa (to Germany).

In order to improve water footprint analyses (i.e., to quantify impacts of consumption, trade and export production in the source regions), we characterized some of the main source countries and regions within these countries, which are producing food for Berlin, in terms of their water scarcity and other indicators such as undernourishment and stunting. Table 3 lists the main non-industrialized exporting countries of virtual water to Berlin in descending order (and Germany for comparison), with some key water and food-security related parameters. Water scarcity at national level is expressed as the ratio of green plus blue water availability for food production divided by total food water requirement (according to Rockström et al., 2009). Please note that these food water requirements were calculated according to the crop water productivity of the respective country (Gerten et al., 2011). Five of the listed export countries have ratios close to or even lower than one and hence are food water scarce. Only in 3 of the countries, blue water contributes significantly more than ca. $1 \%$ to food production. Most of the countries listed have $10 \%$ or more undernourished population and nutritional stunting rates (children under 5) of more than $30 \%$ and hence can be considered food insecure. Note that industrialized countries are excluded from Table 3, because they are assumed to be able to mitigate water scarcity through investments (Vörösmarty et al., 2010). 
Table 3. Characterization of Berlin's largest non-industrialized virtual water source countries in descending order: total (green plus blue) water availability for food production and food water requirement $\left(\mathrm{m}^{3}\right.$ per capita and year), ratio of total water availability to food water requirement (or water-limited food self-sufficiency potential), blue water fraction in food production, prevalence of undernourishment in total population, and nutritional stunting among children under $5 \mathrm{yr}$.

\begin{tabular}{|c|c|c|c|c|c|c|}
\hline $\begin{array}{l}\text { Source } \\
\text { country }\end{array}$ & $\begin{array}{r}\text { Food water } \\
\text { availability } \\
\mathrm{m}^{3} \text { cap }^{-1} \mathrm{yr}^{-1}\end{array}$ & $\begin{array}{r}\text { Food water } \\
\text { requirement } \\
\mathrm{m}^{3} \mathrm{cap}^{-1} \mathrm{yr}^{-1}\end{array}$ & $\begin{array}{r}\text { Availability to } \\
\text { requirement } \\
\text { ratio }\end{array}$ & $\begin{array}{r}\text { Blue water } \\
\text { fraction in food } \\
\text { production [\%] }\end{array}$ & $\begin{array}{r}\text { Undernourished } \\
\text { population } \\
\% \text { of total }\end{array}$ & $\begin{array}{r}\text { Nutritional } \\
\text { stunting } \\
\% \text { of total }\end{array}$ \\
\hline Brazil & 22358 & 1268 & 17.6 & 0.3 & 7 & 7 \\
\hline Ivory Coast & 6233 & 1822 & 3.4 & 0.1 & 21 & 39 \\
\hline Indonesia & 7485 & 1029 & 7.3 & 0.4 & 9 & 40 \\
\hline Colombia & 10677 & 1338 & 7.9 & 0.2 & 13 & 16 \\
\hline Ghana & 3912 & 3325 & 1.2 & 0.02 & $<5$ & 29 \\
\hline Papua/N.G. & 72279 & 2757 & 26.2 & 0 & n.a. & 44 \\
\hline El Salvador & 2567 & 2692 & 0.9 & 1.8 & 12 & 25 \\
\hline Nigeria & 3017 & 2208 & 1.4 & 0.4 & 9 & 41 \\
\hline Vietnam & 2560 & 930 & 2.7 & 15.6 & 9 & 43 \\
\hline Kenya & 1589 & 2083 & 0.8 & 0.1 & 30 & 35 \\
\hline Honduras & 7672 & 2378 & 3.2 & 1.0 & 10 & 30 \\
\hline Guatemala & 5722 & 2173 & 2.6 & 1.0 & 30 & 54 \\
\hline India & 1054 & 1473 & 0.7 & 47 & 18 & 48 \\
\hline Peru & 6452 & 1116 & 5.8 & 4.1 & 11 & 28 \\
\hline Cameroon & 8978 & 2720 & 3.3 & 0.3 & 16 & 36 \\
\hline Ecuador & 5098 & 1448 & 3.5 & 1.3 & 18 & 29 \\
\hline Ethiopia & 1404 & 2822 & 0.5 & 1.8 & 40 & 51 \\
\hline Germany & 1179 & 517 & 2.3 & 0.6 & n.a. & 1 \\
\hline
\end{tabular}

Often export food production is concentrated in certain regions of a country, so that national averages (e.g., of water scarcity) are not sufficient for deriving true footprints (impacts in the source region). Hence we characterize in more detail the situation in export regions of Brazil and the three West African countries Ivory Coast, Ghana, and Nigeria (the last two having food water availability to demand ratios close to 1 ).

Brazil, the largest international provider of virtual water for Berlin, is also the least food-insecure source country listed in Table 3. Also, Brazil is not water scarce at national level (nor is Brazil overdrawing its bio-capacity according to WWF 2012). However, when zooming into the main soy export production region, the Cerrado, per capita green plus blue food water availability there is much lower than national average, close to that of Germany (ca. $1100 \mathrm{~m}^{3} \mathrm{cap}^{-1} \mathrm{yr}^{-1}$, based on LPJmL calculations). While currently $98-99 \%$ of soy production in Brazil is rainfed (Brazilian National Water Agency; http://www.ana.gov.br (last access: 27 August 2013); Mekonnen and Hoekstra, 2010), dams, water transfers and irrigation schemes are increasingly coming online, intended to reduce dependence on rainfall variability. So, the rapidly growing exports (Brazil's soy exports to Germany for example have more than tripled between 1990 and 2010; FAOSTAT; http://faostat3.fao.org/home/index.html (last access: 27 January 2013)) are also beginning to compete for limited blue water resources in the Brazilian Cerrado.
Berlin's virtual water imports from Ivory Coast, Ghana and Nigeria are primarily associated with rainfed cocoa (and to a minor extent also with coffee). National-level data on food water availability and requirement, as well as food insecurity (see Table 3 ) indicate that export production may compete with demands for local staple crop production. However, cocoa and coffee are primarily grown in the humid (and subhumid transition) zone(s) of these countries, where rainfall is relatively high, crops are not irrigated and food security is higher than in the drier north which often has prolonged hunger phases associated with droughts.

So in the case of soy from Brazil, water stress in the main export production region is higher than national average, in the case of cocoa and coffee from Ivory Coast, Ghana and Nigeria water stress (and food insecurity) in the main export production region is lower than national average.

Initial comparison of export production regions as identified by our global top down analysis with those from bottomup local and national data, shows relatively good agreement in the case of soy production in Brazil (Figure 5a), and for cocoa production in Nigeria (Fig. 5b), but a significant mismatch in Ivory Coast and Ghana where the globally available production data (from Monfreda et al., 2008) as presented on the left hand side do not match the actual spatial distribution as derived from local data (right hand side of Fig. 5b). Expert consultations confirmed these discrepancies between global crop data sets and sub-national crop production patterns. 
Note that for Nigeria, Ivory Coast and Ghana only production data, but no specific export production data are available, which is not a problem though, given that there is negligible domestic consumption (while in Brazil $30 \%$ of soy production is not exported but domestically consumed; FAOSTAT http://faostat3.fao.org/home/index.html (last access: 27 January 2013)).

\section{Discussion}

\subsection{Towards true water footprints: detailed analysis of virtual water flows}

Our analysis of virtual water flows at high spatial resolution ( 5 arcmin) allows for the first time to globally consistently assess and separate domestic and international virtual water flows, and accordingly also flows from and to smaller regions at sub-national scale, such as cities. Of the three cities analyzed, only Berlin imports the major share of its virtual water from abroad, consistent with the fact that Germany's total food imports are much higher than those of Nigeria and even those of India, despite its much smaller population (FAOSTAT - http://faostat3.fao.org/faostat-gateway/go/ to/download/T/TP/E (last access: 5 January 2014)). But it should be noted that Delhi and Lagos may soon also depend on international imports, given that Delhi's population is projected to grow from 15 million to about 50 million and Lagos' from 10 million to about 40 million by 2050 (see data for these cities in UNDESA, 2011), while domestic water resources for food production are already largely exploited (see Table 3). Our results are in line with the results of Fader et al. (2011) who also show much higher international contributions to Germany's food water requirements, compared to India and Nigeria, only their results are less pronounced since they did not include coffee and cocoa which together account for $28 \%$ of Berlin's virtual water import.

The fact that Berlin's per capita virtual water imports are only half of those of Lagos', but $50 \%$ higher than Delhi's can be explained by a combination of (opposing) factors, that is, the much higher water productivity in large parts of Berlin's source regions, the higher per capita kcal consumption, and a much larger fraction of water-intensive soy (livestock feed) and coffee and cocoa imports to Berlin, compared to Delhi and Lagos. We have not accounted in our analysis for imports of livestock products for which soy (or other feed crops) may have been used, which would have increased the footprints further. Vanham et al. (2013a) estimate for the EU that the consumption of livestock products is responsible for more than half of the total water footprint related to the consumption of agricultural products. WWF (2009) largely confirms this analysis, ranking coffee, cocoa, other oil seeds, cotton (not included in our analysis), and soy as the top five commodities in terms of virtual water imports (to Germany).
We find that the conventional assumption of growing dietary water requirements with higher income (e.g., Lundqvist et al., 2008) up to a certain saturation level, needs to be modified somewhat, by balancing higher water demands of more luxurious diets (more livestock products and more luxury foods such as coffee and cocoa) with the higher crop water productivities in some of the main food source regions (Brauman et al., 2013). Germany produces 8 times more kcals per liter of consumptive water use (under current crop mix) than Nigeria, 12 times more than Ghana, 6 times more than Ivory Coast, and 5 times more than India (Gerten et al., 2011).

Our analysis also differentiates between green and blue virtual water imports, because these two types of water, associated with traded crops have different opportunity costs and cause different footprints in the source regions. Only about $0.5 \%$ of the virtual water imports of Lagos and $2 \%$ of those of Berlin but $42 \%$ of Delhi's imports are based on blue water consumption (i.e., associated with irrigation water withdrawals). Hence Delhi's food consumption and imports impact blue water resources in the source regions much more strongly and directly than consumption and imports of Berlin or Lagos. Imports based on rainfed agriculture compete in the source regions with other land uses and ecosystems and their services (Foley et al., 2011) also for the green water they consume. But rainfed agriculture also affects blue water availability, either negatively or positively through (i) changes in land surface hydrology (agricultural intensification for export production or as a result of foreign direct investment can increase evapotranspiration and hence decrease blue water availability, compared to previous land uses such as grazing or extensive agriculture, see e.g., Bossio et al. (2012) and Ridoutt and Pfister (2010) for how to account for that effect) and/or (ii) reducing the need for blue water use for irrigation, if rainfed crop productivity and production can be increased (Rockström et al., 2009). The impacts on water scarcity and the opportunity costs of green and blue crop water use for export agriculture strongly depend on the specific local context in the source region.

\subsection{Towards true water footprints: detailed analysis of local context in source regions}

In order to move beyond "shoesizes" (Pfister and Hellweg, 2009) (i.e., volumes of virtual water associated with bilateral trade flows) towards true footprints (i.e., impacts of consumption and export production), we have assessed the water- and food-related context in some of the source regions of Berlin. We found that significant fractions of its virtual water imports originate from water-scarce and/or foodinsecure countries (Table 3), as driven by comparative advantages that these countries have in climate (e.g., cocoa and coffee only being produced in tropical climates), land (e.g., Brazil's land availability - measured as the ratio of biocapacity to ecological footprint - being much higher than that of Germany, WWF, 2012), labor, capital or other production 

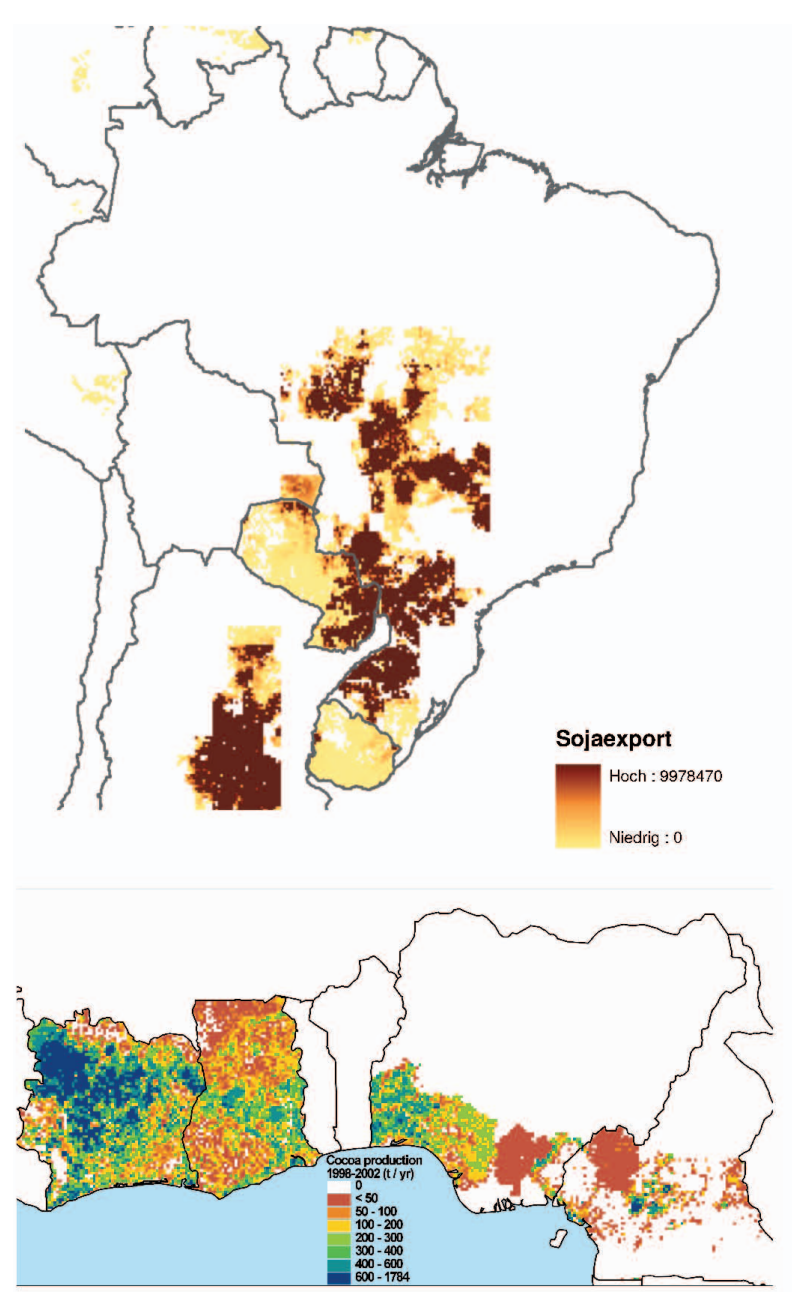
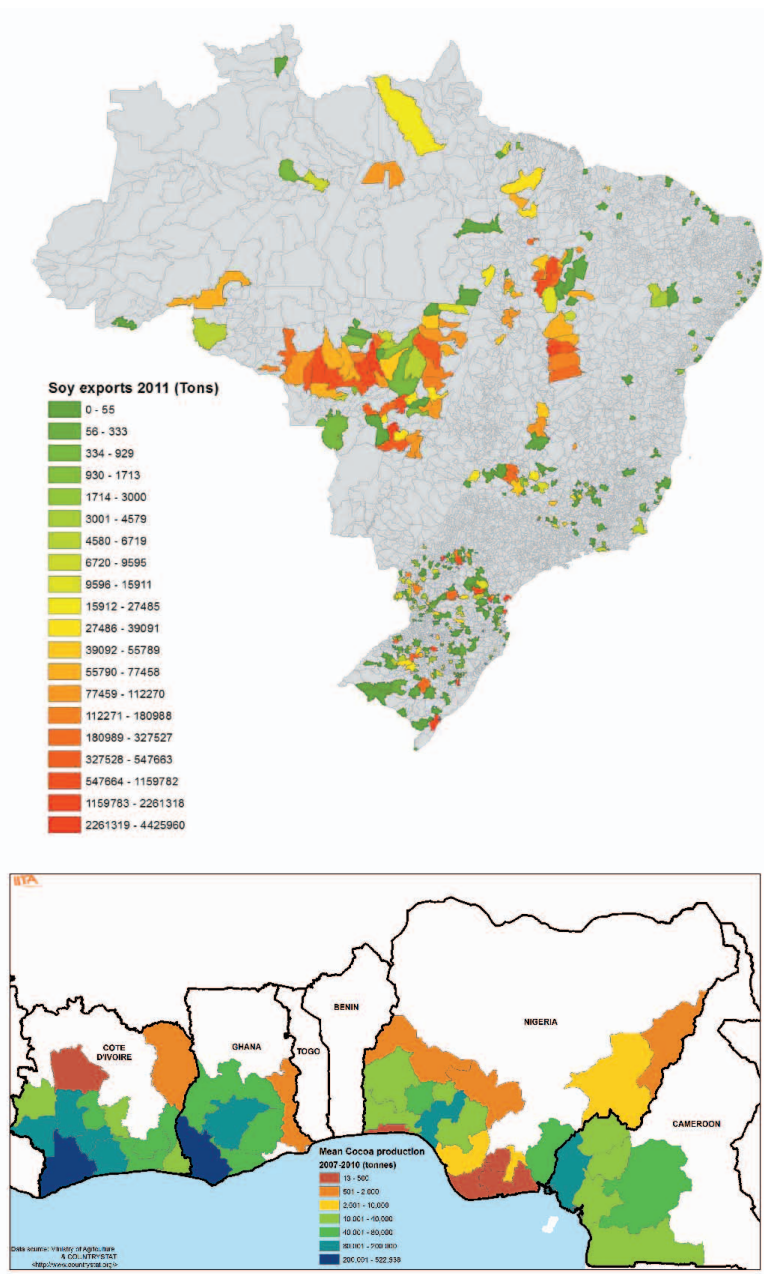

Fig. 5. Comparison of global GCWM analysis with national census data. (a) Main soy surplus and export production regions in Brazil left: according to global GCWM analysis (in kg per grid cell per year); right: municipal-level export production data in tons, after Municipal Production Census 2011, IBGE. (b) Main cocoa production regions in West Africa - left: cocoa production in Ivory Coast, Ghana, Nigeria and Cameroon according to GCWM analysis (in tons per grid cell per year); right: municipal-level production in Nigeria in tons (Hauser, personal communication, 2013).f

factors. Moreover commodity prices do not always reflect resource scarcities in the producing regions, due to subsidies and other market distortions. Given the very low blue water fractions of Berlin's major international virtual water imports, associated with coffee, soy and cocoa (not considering cotton with a high blue water fraction), separate footprint analysis for blue virtual water exports is not necessary.

Since national averages (in particular for large countries such as Brazil) are not suitable for deriving local impacts of export production, we further assessed the local conditions in some of the main source regions in Brazil and West African countries. While at national level the per capita water availability for food production is much less constrained in Brazil than in Germany (Table 3), it is much lower in the main soy exporting region (Cerrado, see Fig. 5a), comparable to that of Germany. Given that crop water productivity of soy and other major crops grown in Brazil is only about half of that of major crops grown in Germany, the Cerrado is in fact relatively more food-water constrained. Furthermore, water quality degradation from industrial soy production which is responsible for about $25 \%$ of total Brazilian pesticide use (Altieri and Pengue, 2005) - reduces the availability of clean water further. Mekonnen et al. (2010) propose to include water pollution in footprint analyses (calculating so-called "grey-water footprints"), but there are methodological difficulties involved, when integrating real quantities of water consumed with potential quantities of water required for diluting pollution. Furthermore, so-called "leakage" or indirect land use change, caused by expanding soy production in the Cerrado, pushes other land uses such as cattle ranching deeper into neighboring Amazonia, where it causes rapid deforestation with potentially far-reaching consequences for moisture recycling, precipitation and water availability in other parts of South America (Nobre and 
Borma, 2009; Marengo et al., 2009). These indirect waterrelated effects of export production add another layer of complexity to water footprint analyses.

Food production in Ghana and Nigeria is significantly more water constrained at national level than in Germany, due to much lower agricultural water productivities (Table 3), caused by lower agricultural inputs, underperforming extension systems and other factors. However, cocoa and coffee export production are concentrated in the more humid (and also more food secure) parts of these West African countries (see Fig. 5b), which have higher water availabilities for food production than the national average. These gradients of water availability (and food security) within the respective source country point at another (economic) facet of "local context": the capacity to distribute food surpluses internally from well-endowed to critically scarce regions, which depends in particular on transport infrastructure, and which could be measured, for example, by the travel time to markets (Nelson, 2008). When this internal food distribution capacity is low, resource exploitation for export production may aggravate water scarcity or food insecurity of the local - in particular the most marginalized - population. Travel distances may also be suitable for our own analysis as an alternative to Euclidean distances, when distributing surplus crop production to other grid cells (see first assumption in the Methods section). In some countries, infrastructure may also determine distribution of imports more strongly than population fractions in the respective grid cell (second assumption in the Methods section). Our assumption that per capita food consumption is the same everywhere within a country may somewhat bias the analysis, as in large countries like India diets in one part may be quite different from those in another part (e.g., wheat versus rice as staple crops). In addition, this assumption is likely to underestimate food consumption of cities in developing countries, as the diet there is richer in meat and other water-intensive products than in the rest of the country (e.g., Romanik, 2007). So this assumption will have to be further refined for different country contexts, once consistent global data become available. However, we did not find evidence that the assumption does not hold for Berlin, a city in a developed country.

A closer look at production systems shows that cocoa in Nigeria is mostly shaded by other trees, some being remnants of former forest vegetation. These systems are not high yielding but have been stable over more than 50 , sometimes $100 \mathrm{yr}$. In Ghana and Ivory Coast on the other hand, most cocoa systems are younger, planted with improved varieties and less shaded or in open light. Yields are usually higher in these younger systems (and hence they reduce competition for green water and land with local staple crop production or other ecosystems), yet pesticide and fertilizer inputs and associated water quality degradation are also higher than in traditional shaded systems. The long-term sustainability another determinant of local impact and water footprints - is potentially traded off against yield maximization.
We have limited this water footprint analysis to opportunity costs, but of course there are also benefits derived from export production. For example in Ivory Coast, Ghana and Nigeria the cash crops cocoa and coffee are important sources of income and foreign exchange earners, at equal or higher economic water productivity than staple crops. A comprehensive footprint analysis has to weigh environmental and socio-economic costs and benefits.

\section{Conclusions}

\subsection{Operationalizing water footprints}

The Global Footprint Networks describes the objective of footprint analyses as "allow[ing] to track a city's... demand on natural capital, and to compare this demand with the amount of natural capital actually available....shed light on the region's constraints or future liabilities in comparison with other regions of the world" - http://www.footprintnetwork.org/en/index.php/GFN/page/ footprint_for_cities (last access: 27 January 2013).

Our analysis contributes to this goal, aiming at operationalizing water footprints for guiding sustainable consumption and production. We find that water footprints of luxurious diets such as those of Berlin materialize to a large extent in distant, sometimes water-scarce and food-insecure countries or regions thereof. These countries may not be in the position to fully ensure sustainable water management through the appropriate policy making at national level, as suggested by Wichelns (2010), given that they are subject to strong external pressures on their water resources, driven by globalization, trade and foreign direct investment. These pressures, which cause resource exploitation and in some cases also degradation, must be addressed, when striving for more sustainable consumption and production.

\subsection{Opportunities for more sustainable consumption}

We have identified indicators to measure the sustainability of consumption, by specifying in more spatial detail than previously available the origin of crop commodities and associated virtual water flows, and the local conditions in the source regions. A case in point is the (over-) consumption of meat by wealthier populations and population groups, which is responsible for a large fraction of water footprints of their diets (Vanham et al., 2013). Berlin's footprint of meat consumption (for which we use soy import for livestock feed as a proxy) puts water resources in the Brazilian Cerrado, in the adjacent Amazon, and beyond at risk. Accordingly, Berlin's footprint can be reduced by lower meat consumption.

However, the case of Berlin also demonstrates the difficulty of deriving recommendations for sustainable consumption from footprint analyses, for example, when assessing the large water footprints associated with cocoa (and coffee) consumption, which materialize in West African countries. 
While cocoa export production there competes for land and green water with staple crop production for domestic use and also with other ecosystems and their services, it also provides income and hence a means for improving access to food for the local population and eventually also for improving agricultural productivity through better management. Hence it is unlikely that reduced cocoa consumption in Berlin and subsequent reduction of export production in West Africa and re-allocation of water to staple food crops for local consumption would solve the region's food security problems. These socio-economic impacts of export production are yet to be integrated with environmental impacts in water footprint analyses.

\subsection{Opportunities for more sustainable production}

We introduced crop water productivity (the reverse of virtual water content) in our water footprint analysis, explaining that way the much lower per capita water footprint of Berlin compared to Lagos, despite its more luxurious diets. The low water productivity in large parts of sub-Saharan Africa is primarily explained by agricultural management and climatic factors. Fertilizer inputs are very low (Potter et al., 2010) and area equipped for irrigation is at or below $1 \%$ of cropland (Portmann et al., 2010) in the three West African countries assessed in this study, missing large opportunities for increasing water productivity (and hence reducing footprints) under the given climate. Agro-ecological research has identified diverse and multi-functional (domestic and export production) systems, for example, cocoa or coffee production shaded by banana trees, for sustainably increasing overall resource productivity and system resilience (Tscharnke et al., 2012). Export production and also foreign direct investment can contribute knowledge and technologies for such type of sustainable intensification (Hoff et al., 2012). However, there are no blanket solutions, but opportunities are very specific to the respective natural resource (and socio-economic) context. Global top-down approaches to water footprints need to be complemented by context-specific analyses of local costs, benefits and opportunities of export production. Opportunities for sustainable consumption and production (often separated by large distances) are linked through the food supply chains along which many additional opportunities for reducing footprints (also other than water) arise.

\subsection{Next steps in footprint analyses}

There are a number of uncertainties in the above analysis, for example, related to grid-level crop production and export production, re-exports, sub-national variation of diets in particular differences between urban areas and the rest of the country, and local impacts of export production. Hence further operationalization of water footprints, for identification of opportunities for sustainable consumption and production, critically hinges on improved data availability on
1. sub-national export production pattern, improving our initial (top-down) analyses of virtual water flows at high resolution;

2. sub-national and context-specific conditions in source regions (e.g., green and blue water scarcity and opportunity costs, production systems, and food insecurity) for identifying opportunities for more sustainable production; and

3. specific diets of cities and population groups, in cases where these deviate from national averages, and additional food characteristics beyond kcals such as nutritional value, for identifying opportunities for more sustainable consumption.

Moreover, water footprint analysis to date has almost exclusively been based on bi-lateral trade flow data for the major commodities (one exception is Feng et al., 2011). This is not sufficient in view of the increasingly complex multi-national (and also multi-sectoral) supply chains, from primary crop production, through various processing steps, to the final consumer. A way forward towards fully consumption-based accounting and detailed tracing of virtual green and blue water flows through these supply chains and also comprehensively taking care of re-exports may be provided by multiregional input-output (MRIO) analysis. Initial work of that type can be found, for example, in Lenzen et al. (2013) or Hoff et al. (2013).

Lastly, for guiding sustainable consumption and production, "multi-dimensional" footprints will be required (see Galli et al., 2012; Ridoutt and Pfister, 2013). Green and blue water footprints as described here need to be harmonized and integrated with land, ecological, nitrogen, carbon and possibly other footprints - also acknowledging the interdependencies among the different natural resources as input factors in food production and their utilization in the respective source regions. There is still a long way to go in terms of data consolidation, method development and harmonization of different footprint approaches (Vanham and Bidoglio, 2013b). Nevertheless, awareness raising and education on footprints should occur even without having a perfect database. This could be initially focused on informing consumers in developed countries about the (water and other) footprints of meat consumption and associated environmental externalities in the source regions (e.g., via certified and labeled products). New scientific knowledge has to feed into these indicators for sustainable consumption and production as it becomes available.

\section{Supplementary material related to this article is available online at http://www.hydrol-earth-syst-sci.net/ 18/213/2014/hess-18-213-2014-supplement.pdf.}


Acknowledgements. We acknowledge the constructive comments by the three reviewers, which significantly improved the manuscript. The contribution of M. Fader was supported by the Labex OT-Med (no ANR-11-LABX-0061) and the A*MIDEX project (no ANR-11-IDEX-0001-02).

Edited by: J. Liu

\section{References}

Altieri, M. A. and Pengue, W. A.: Roundup ready soybean in Latin America: a machine of hunger, deforestation and socio-ecological devastation, RAP-AL Uruguay, available at: http://www.grain.org/article/entries/ 588-gm-soybean-latin-america-s-new-colonizer, 2005.

Anderson, K.: Globalization effects on world agricultural trade, 1960-2050, Philos. T. Roy. Soc., 365, 3007-3021, 2010.

Anseeuw, W., Alden Wily, L., Cotula, L., and Taylor, M.: Land Rights and the Rush for Land: Findings of the Global Commercial Pressures on Land Research Project. International Land Coalition (ILC), Rome, Italy, 2012.

Bicheron, P., Defourny, P., Brockmann, C., Schouten L., Vancutsem C., HUC, M., Bontemps, S., Leroy, M., Achard, F., Herold, M., Ranera, F., and Arino, O.: GLOBCOVER Products description and validation report, European Space Agency, Paris, European Space, 2008.

Bossio, D., Erkossa, T., Dile, Y., McCartney, M., Killiches, F., and Hoff, H.: Water implications of foreign direct investments in Ethiopia, Water Alternatives, 5, 223-242, 2012.

Brauman, K. A., Siebert, S., and Foley, J. A.: Improvements in crop water productivity increase water sustainability and food security - a global analysis, Environ. Res. Lett. 8, 024030, doi:10.1088/1748-9326/8/2/024030, 2013.

Bruckner, M., Giljum, S., Lutz, C., and Wiebe, K. S.: Materials embodied in international trade - Global material extraction and global material consumption between 1995 and 2005, Global Environ. Chang., 22, 568-576, 2012.

Chapagain, A. K. and Hoekstra, A. Y.: The water needed to have the Dutch drink coffee, Value of Water Research Report Series No.14, UNESCO-IHE, Delft, the Netherlands, 2003.

Chapagain, A. K. and Hoekstra, A. Y.: Water footprints of nations, Value of Water Research Report Series No.16 Volume 1, UNESCO-IHE, Delft, the Netherlands, 2004.

Dalin, C., Konar, M., Hanasaki, N., Rinaldo A., and Rodriguez-Iturbe, I.: Evolution of the global virtual water trade network, Proc. Natl. Acad. Sci., 109, 5989-5994, doi:10.1073/pnas.1203176109, 2012.

Daniels, P. L., Lenzen, M., and Kenway, S. J.: The ins and outs of water use - a review of multi-regional input-output analysis and water footprints for regional sustainability analysis and policy, Econ. Syst. Res., 23, 353-370, 2011.

Döll, P., Hoffmann-Dobrev, H., Portmann, F. T., Siebert, S., Eicker, A., Rodell, M., Strassberg, G., and Scanlon, B.: Impact of water withdrawals from groundwater and surface water on continental water storage variations, J. Geodyn., 59-60, 143-156, 2012.
Erb, K.-H., Krausmann, F., Lucht, W., and Haberl, H.: Embodied HANPP: Mapping the spatial disconnect between global biomass production and consumption, Ecol. Econ. 69, 328-334, 2009.

Fader, M., Gerten, D., Thammer, M., Heinke, J., Lotze-Campen, H., Lucht, W., and Cramer, W.: Internal and external green-blue agricultural water footprints of nations, and related water and land savings through trade, Hydrol. Earth Syst. Sci., 15, 1641-1660, doi:10.5194/hess-15-1641-2011, 2011.

Faramarzi, M., Yang, H., Mousavi, J., Schulin, R., Binder, C. R., and Abbaspour, K. C.: Analysis of intra-country virtual water trade strategy to alleviate water scarcity in Iran, Hydrol. Earth Syst. Sci., 14, 1417-1433, doi:10.5194/hess-14-1417-2010, 2010.

Feng, K., Chapagain, A., Suh, S., Pfister, S., and Hubacek, K.: Comparison of bottom-up and top-down approaches to calculating the water footprints of nations, Econ. Syst. Res., 23, 4, 371-385, 2011.

Foley, J. A., Defries, R., Asner, G. P., Barford, C., Bonan, G., Carpenter, S. R., Chapin, F. S., Coe, M. T., Daily, G. C., Gibbs, H. K., Helkowski, J. H., Holloway, T., Howard, E. A., Kucharik, C. J., Monfreda, C., Patz, J. A., Prentice, I. C., Ramankutty, N., and Snyder, P. K.: Global consequences of land use, Science, 39, 570-574, 2005.

Foley, J. A., Ramankutty, K. N., Brauman, K. A , Cassidy, E. S., Gerber, J. S., Johnston, M., Mueller, N. D., O’Connell, C., Ray, D. K., West, P. C., Balzer, C., Bennett, E. M., Carpenter, S. R., Hill, J., Monfreda, C., Polasky, S., Rockström, J., Sheehan, J., and Siebert, S., Tilman D., Zaks D.P.: Solutions for a cultivated planet, Nature, 478, 337-342, 2011.

Galli, A., Wiedmann, T., Ercin, E., Knoblauch, D., Ewing, B., and Giljum, S.: Integrating ecological, carbon and water footprint into a "footprint family" of indicators: definition and role in tracking human pressure on the planet, Ecol. Indic., 16, 100-112, 2012.

Gerten, D., Heinke, H., Hoff, H., Biemans, H., Fader, M., and Waha, K.: Global Water Availability and Requirements for Future Food Production, J. Hydrometeorol., 12, 885-899, 2011.

GHI: Global Hunger Index, IFPRI, Welthungerhilfe, Concern Worldwide, Bonn, Washington, DC, Dublin, 2011.

Hanasaki, N., Inuzuka, T., Kanae, S., and Oki, T.: An estimation of global virtual water flow and sources of water withdrawal for major crops and livestock products using a global hydrological model, J. Hydrol., 384, 232-244, 2010.

Hoekstra, A. Y. and Mekonnen, M. M.: Global water scarcity: monthly blue water footprint compared to blue water availability for the world's major river basins, Value of Water Research Report Series No. 53, UNESCO-IHE, Delft, the Netherlands, 2011.

Hoekstra, A. Y. and Mekonnen, M. M.: Reply to Ridoutt and Huang: From water footprint assessment to policy, Proc. Natt. Acad. Sci., 109, p. 1425, 2012.

Hoff, H.: Global Water Resources and their Management, Cosust., 1, 141-147, 2009.

Hoff, H., Gerten, D., and Waha, K.: Green and blue water in Africa - How foreign direct investment can support sustainable intensification, in: Handbook on land and water grabs in Africa, edited by: Keulertz, M. and Allan, A., Routledge, London, New York, 2012.

Hoff, H., Dawkins, E., Persson, A., Weitz, N., and West, C.: SEI feasibility study towards a WWF programme "EU Policies for One Planet”, under revision, 2013. 
Lenzen, M., Moran, D., Bhaduri, A., Kanemoto, K., Bekchanov, M., Geschke, A., and Foran, B.: International Trade of Scarce Water, Ecol. Econ., 74, 78-85, 2013.

Liu, J. and Savenije, H. H. G.: Food consumption patterns and their effect on water requirement in China, Hydrol. Earth Syst. Sci., 12, 887-898, doi:10.5194/hess-12-887-2008, 2008.

Liu, J. and Yang, H.: Spatially explicit assessment of global consumptive water uses in cropland: Green and blue water, J. Hydrol., 384, 187-197, 2010.

Lundqvist, J., de Fraiture, C., and Molden, D.: Saving Water: From Field to Fork - Curbing Losses and Wastage in the Food Chain, SIWI Policy Brief, Stockholm, 2008.

Ma, J., Hoekstra, A. Y., Wang, H., Chapagain, A. K., and Wang, D.: Virtual versus real water transfers within China, Philos. T. Roy. Soc. B, 361, 835-842, 2006.

Marengo, J., Nobre, C. A., Betts, R. A., Cox, P. M., Sampaio, G., and Salazar, L.: Global warming and climate change in Amazonia: Climate-vegetation feedback and impacts on water resources, in Amazonia and Global Change, Geoph. Monog. Series, 186, edited by: Keller, M., Bustamante, M., Gash, J., and Silva Dias, P., 273-292, AGU, Washington, D. C., doi:10.1029/2008GM000743, 2009.

Mekonnen, M. M. and Hoekstra, A. Y.: The green, blue and grey water footprint of crops and derived crop products, Vol. 2, Value of Water Research Report Series No. 47, Delft, The Netherlands, 2010.

Monfreda, C., Ramankutty, N., and Foley, J. A.: Farming the planet. Part 2: the geographic distribution of crop areas, yields, physiological types, and NPP in the year 2000, Global Biogeochem. Cy., 22, GB1022, doi:10.1029/2007GB002947, 2008.

Nelson, A.: Estimated travel time to the nearest city of 50000 or more people in year 2000. Global Environment Monitoring Unit Joint Research Centre of the European Commission, Ispra Italy, available at: http://gem.jrc.ec.europa.eu/ (last access: 27 January 2013), 2008.

Nobre, C. A. and Borma, L. D. S.: Tipping points for the Amazon forest, Cosust, 1, 28-36, 2009.

Pfister, S. and Hellweg, S.: The water "shoesize" vs. footprint of bioenergy, Proc. Natl. Acad. Sci., 106, E93-E94, 2009.

Pfister, S., Bayer, P., Koehler, A., and Hellweg, S.: Environmental impacts of water use in crop production: hotspots and tradeoffs with land use, Environ. Sci. Technol., 45, 5761-5768, 2011.

Portmann, F. T., Siebert, S., and Döll, P.: MIRCA2000 - Global monthly irrigated and rainfed crop areas around the year 2000: A new high-resolution data set for agricultural and hydrological modeling, Global Biogeochem. Cy., 24, Gb1011, doi:10.1029/2008GB003435, 2010.

Potter, P., Ramankutty, N., Bennett, E. M., and Donner S. D.: Characterizing the spatial patterns of global fertilizer application and manure production, Earth Interact., 14, 1-22, 2010.

Ridoutt, B. G. and Huang, J.: Environmental relevance - the key to understanding water footprints, Proc. Natl. Acad. Sci., 109, E1424, doi:10.1073/pnas.1203809109, 2012.

Ridoutt, B. G. and Pfister, S.: A revised approach to water footprinting to make transparent the impacts of consumption and production on global freshwater scarcity, Global Environ. Chang., 20, 113-120, 2010.
Ridoutt, B. G. and Pfister, S.: Towards an integrated family of footprint indicators, J. Ind. Ecol., 17, 337-339, 2013.

Rockström J., Falkenmark, M., Karlberg, L., Hoff, H., Rost, S., and Gerten, D.: Future Water Availability for Global Food Production: The Potential of Green Water for Increasing Resilience to Global Change, Water Resour. Res., 45, W00A12, doi:10.1029/2007WR006767, 2009.

Romanik, C.: An urban-rural focus on food markets in Africa, Urban Institute, Washington D.C., available at: http://www.urban. org/url.cfm?ID=411604 (last access: 27 January 2013), 2007.

Rost, S., Gerten, D., Bondeau, A., Lucht, W., Rohwer, J., and Schaphoff, S.: Agricultural green and blue water consumption and its influence on the global water system. Water Resour. Res., 44, W09405, doi:10.1029/2007WR006331, 2008.

Shiklomanov, I. A.: Appraisal and Assessment of World Water Resources, Water Int., 25, 11-32, 2000.

Siebert, S. and Döll, P.: Quantifying blue and green virtual water contents in global crop production as well as potential production losses without irrigation, J. Hydrol., 384, 198-217, 2010.

Tscharnke, T., Clough, Y., Wanger, T. C., Jackson, L., Motzke, I., Perfecto, I., Vandermeer, J., and Whitbread, A.: Global food security, biodiversity conservation and the future of agricultural intensification, Biol. Conserv., 151, 53-59, 2012.

UNDESA: World urbanisation prospects, the 2011 revision, United Nations Department of Economic and Social Affairs, WP 224, New York, 2011.

UNPD: United Nations Population Division, World Urbanization Prospects 2011 - Urban and Rural Population, available at: http:// esa.un.org/unpd/wup/unup/ (last access: 27 January 2013), 2011.

Vanham, D. and Bidoglio, G.: A review on the indicator water footprint for the EU28, Ecol. Indic., 26, 61-75, $2013 \mathrm{~b}$.

Vanham, D., Mekonnen, M. M., and Hoekstra A. Y.: The water footprint of the EU for different diets, Ecol. Indic., 32, 1-8, $2013 \mathrm{a}$.

Verma, S., Kampman, D. A., Van der Zaag, P., and Hoekstra, A. Y.: Going against the flow: A critical analysis of inter-state virtual water trade in the context of India's National River Linking Programme, Phys. Chem. Earth, 34, 261-269, 2009.

von Witzke, H. and Noleppa, S.: EU agricultural production and trade: Can more efficiency prevent increasing "land-grabbing" outside of Europe? Research Report, University of Piacenca, Milano, Italy, Berlin, Germany, 2010.

Vörösmarty, C. J., McIntyre, P. B., Gessner, M. O., Dudgeon, D., Prusevich, A., Green, P., Glidden, S., Bunn, S. E., Sullivan, C. A., Reidy Liermann, C., and Davies, P. M.: Global threats to human water security and river biodiversity, Nature, 467, 555-561, 2010.

Wichelns, D.: Virtual Water and Water Footprints Offer Limited Insight Regarding Important Policy Questions, Int. J. Water Resour. D., 26, 639-651, 2010.

WTO: World Trade Report 2010, Trade in natural resources, Geneva, Switzerland, 2010.

WWF: Der Wasserfußabdruck Deutschlands, WWF, Frankfurt, Germany, 2009.

WWF: Living Planet Report, WWF, Gland, Switzerland 2012. 